\title{
Örgütsel Özdeşleşmenin İş Tatmini Üzerine Etkisinde İşe Adanmışlığın Aracı Rolünün Belirlenmesine Yönelik Bir Araştırma
}

\section{A Research on Determination of the Mediation Role of Work Engegament in the Effect of Organizational Identification on Job Satisfaction}

\section{Dr. Öğr. Üyesi Ali Bayram ${ }^{1}$}

Başvuru Tarihi: 18.10 .2019

Kabul Tarihi: 30.12 .2019

Öz

Bu çalışmanın amacı, örgütsel özdeşleşmenin iş tatmini üzerine etkisinde işe adanmışlığın aracı rol oynayıp oynamadiğını tespit etmektir. Kayseri'de faaliyet göstermekte olan kamu hastanelerinde çalışmakta olan sağlık çalışanları üzerinde alan araştırması gerçekleştirilmiştir. Yapılan alan araştırması sonucunda 427 katılımcıdan veri elde edilmiştir. Araştırma kapsamında frekans analizi, güvenilirlik analizi, doğrulayıcı faktör analizi, korelasyon analizi ve regresyon analizinden faydalanılmıştır. Yapılan analizler sonucunda işe adanmışlığın örgütsel özdeşleşmenin iş tatmini üzerindeki etkisinde kısmi aracılık rolü oynadığı tespit edilmiştir.

Anahtar Kelimeler: Örgütsel Özdeşleşme, İşe Adanmışlık, Iş̧ Tatmini

\begin{abstract}
The purpose of this study is to determine whether work engegament plays a mediating role in the effect of organizational identification on job satisfaction. A field study was conducted on health workers working in public hospitals in Kayseri. As a result of the field research, data were obtained from 427 participants. Frequency analysis, reliability analysis, confirmatory factor analysis, correlation analysis and regression analysis were used. As a result of the analyzes, it has been found that work engegament plays a partial mediating role in the effect of organizational identification on job satisfaction.
\end{abstract}

Keywords: Organizational Identification, Work Engagement, Job Satisfaction

\footnotetext{
${ }^{1}$ Samsun Üniversitesi İİBF, ali.bayram@samsun.edu.tr, ORCID: 0000000207320483
} 


\section{Giriş}

Son yıllarda, birçok alanda örgütsel davranışın anlaşılması için sosyal kimlik kuramının faydasını tartışan birçok araştırma ortaya konulmuştur. Teorik olarak, bir kişinin yaptığı iş ve işin özelliklerinin, örgütün sağladığı sosyal kimlikten türetilen motivasyonel güçlerle daha bilişsel değerlendirmelerinin birleşimi, işyerinde davranış ve tutumları genel olarak etkilemektedir. Bunun yanında psikolojik süreçlerden etkilenen iş tatmini konusunda belirsiz olan noktalar vardır. Özellikle iş tatmininin işgörenlerin performansı üzerindeki etkisi göz önüne alındığında belirsiz noktaların aydınlatılması uygulayıcılar açısından faydalı olabilir.

Örgütsel özdeşleşme, bir kişinin çalıştı̆̆ örgüt içinde aidiyet duygusunu ifade eder. İşle ilgili tutumlarda ve örgütsel davranışta örgütsel özdeşleşmenin önemine rağmen, çok az araştırma bunları birbirine bağlayan mekanizmaları doğrudan incelemiştir. Bu noktadan hareketle bu çalışmada örgütsel kimliğin iş tatminine etkisinde işe adanmışlı̆̆ın aracı rolü oynayıp oynamadığı tespit edilmeye çalışılmıştır. Elde edilen bu sonuçlar, örgütsel özdeşleşmenin etkileri hakkında değerli bilgiler sağlar ve çalışma kimliğinin bağlamı olarak sosyal kimliği anlamadaki bazı boşlukları ele alır. Ayrıca ulusal literatür incelendiğinde üç değişken arasındaki ilişkiyi araştıran bir araştırmaya rastlanılmamış olup; uluslararası literatürde sadece bir çalışmaya rastlanılmıştır. İşe adanmışlığın bahsi geçen ilişkide aracı rolünün tespit edilmesinde bootstrapp (yeniden örnekleme) yöntemi kullanılmıştır. Bu yönleri ile çalışmanın literatüre katkı sağlaması beklenmektedir.

\section{Kavramsal Çerçeve}

\section{Örgütsel Özdeşleşme}

Özdeşleşme kavramını ilk kez kullanan Kelman'a (1958) göre “özdeşleşme belirli bir ilişki içinde yer alan kendi kendini tanımlayan bir cevaptır" ve bir bireyin, "başka bir kişi ya da grupla tatmin edici bir ilişki kurmayı, sürdürmeyi ve onlara benzemeyi” kabul etmesi anlamına gelir (Kelman, 1958, s. 52). Buradaki kilit nokta, özdeşleşmenin çalışan ile örgüt arasında bir ilişki biçimi içerdiği ve bu ilişkinin bireyin öz kavramını oluşturduğu fikridir. Ayrıca özdeşleşme, örgütün bireyin inançlarını bir şekilde etkileyebileceği anlamına da gelmektedir (Edwards, 2005. s. 209). Özdeşleşme, bireyin kendini daha büyük bir bütünün parçası olarak algıladığ psikolojik bir durumdur (Rousseau, 1998, s. 217).

Örgütsel özdeşleşme, "birey ile örgüt arasında, bireyin örgütle sosyal bir varlık olarak içten, kendini tanımlayan, duygusal ve bilişsel bir bağ hissettiği bir psikolojik bağlantı” olarak tanımlanmaktadır (Edwards ve Peccei, 2007, s. 30) ve bir üyenin kurumu tanımladığına inandığı aynı özelliklerle kendisini tanımlamasıdır (Dutton vd. 1994, s. 239). Benzer şekilde, Mael ve Ashforth, örgütsel özdeşleşmeyi "bireyin kendisini üyesi olduğu organizasyon açısından tanımlaması" bir kuruluşla birliktelik veya kuruluşa ait olma algısı olarak belirtmektedir (Mael ve Ashforth, 1992, s. 104). Özdeşleşme bireyin sosyal kimliklerinin bir parçası olarak örgütsel kimliğin bir sonucudur (Ashforth ve Mael, 1989). 
Sosyal kimlik, "bireyin bir sosyal gruba (veya gruplara) üyeliği konusundaki bilgisiyle bu üyeliğe bağlı değer ve duygusal önemi ile türeyen bireyin benlik kavramının bir parçası" olarak tanımlanmaktadır (Tajfel, 1978, s. 63).

Ashforth ve Mael (1989) tarafından gerçekleştirilen çalışmada, sosyal kimlik teorisini örgütsel davranış literarüne dahil ederek, örgütsel özdeşleşme ile alakalı aşağıdaki sonuçları açıllamaktadırlar;

- Bir kurum diğer kurumlarla kıyaslandıklarında daha farklı şekilde zihinde konumlanıyorsa, özdeşleşme ihtimali artmaktadır.

- Kurum üyeleri kurum kimliğinin cezbediciliğini büyük oranda hisssettiklerinde, öz saygınlıkları artmakta ve örgütsel özdeşleşme meydana gelmektedir.

- Kurum üyeleri kurumun imajını ne kadar yüksek seviyede hissederse, kurumla özdeşleşme ihtimalleride o seviyede yükselir.

- Çalışan ile kurum arasındaki ortak hedef, birlikte etkileşim, ortak geçmişe sahip olma ve benzerlikle beraber özdeşleşme gelişmektedir, kurum dişındaki kişilerden gelen tehditler, çalışanın kendi grubuna olan özdeşleşme seviyesini yükseltmektedir.

Örgüt ile işgören arasındaki özdeşleşme süreci, iş görenlerin değerleri ile örgütsel kimlik arasında ortak paydaya sahip olmaları sonucunda meydana gelmektedir (Larson ve Pepper, 2003).

Patchen (1970), ise örgütsel özdeşleşmeyi aşağıda ifade edilen 3 oluşumun bir bileşimi olarak kavramsallaştırmaktadır: (1) bireyin diğer örgüt üyeleri ile paylaştığı ilgi alanlarına ve hedeflerine sahip olduğu ortak özelliklerin algılanması; (2) bireyin o kuruma ait olduğunu hissettiği bir dayanışma hissi; ve (3) bireyin örgütsel amaç ve politikalarını desteklemesi ve savunduğu örgüt tarafindan destek gördüğü algısıdır.

Örgütsel özdeşleşme, çalı̧sanların örgütleriyle ilişkileri ile ilgilidir ve kuruluşla "algılanan birlik" olarak tanımlanır (Ashforth ve Mael, 1989). Çalışanlar örgütleriyle kendilerini özdeşleştirdiklerinde iş tatmini ve motivasyon artarken devamsızlık ve işten ayrılma niyetleri azalmaktadır (Lee, 1971).

\section{İş Tatmini}

İş tatmini, iş görenlerin işlerine karşı hissettikleri memnuniyet düzeyidir ve kaynakların mevcudiyeti, ekip çalışması, takip eden denetçiler ve kişisel tutumlar gibi farklı faktörlerle güçlendirilir (Abraham, 2012). İş tatmini, bir çalışanın kendi işine yönelik genel tutumudur. İşinden memnun olan bir iş gören, işe karşı̨ pozitif bir tutum göstermektedir (Robbins, 2000, s. 20). Sosyal bilimciler arasında, iş tatmininin, belirli bir işe pozitif bir duygusal tepki olduğu konusunda yüksek düzeyde bir uzlaşma vardır (Oshagbemi, 2003). İş tatmini üniter bir kavram değildir. Bir çalş̧an, işinin bir yönü ile nispeten tatmin olabilir ve bir veya daha fazla başka yönden tatminsizlik yaşayabilir (Kreitner ve Kinicki, 2004, s. 202). Chirchill vd. (1974), iş tatmini yapısının aşağıdaki bileşenlerden oluştuğunu ifade etmektedir: işin kendisi, diğer çalışanlar, denetim, şirket politikası ve desteği, ücret, terfi ve ilerlemedir. 
- İşin kendisi, çalışanlar için başarı, ilerleme ve büyüme sağlayan ilginç ve önemli bir iş, dahası sorumluluk, özerklik, rol netliği, yöneticilerden geribildirim ve rol çatışması eksikliği iş tatminini artırmaktadır. (Henne ve Locke, 1985: 221-240).

- Diğer çalışanlar, Robbins (2000), dostane ve destekleyici iş arkadaşlarının iş tatmini artışına yol açtığını belirtmiştir.

- Denetim, çalışanlar düşünceli, dürüst, adil ve yetkili denetçilerden hoşlanırlar. Ayrıca iyi bir performans için takdir edilmek, ödüllendirilmek ve karar verme sürecine katılmak isterler (Henne ve Locke, 1985, s. 221-240).

- Şirket politikası, çalışanlar, kendilerine ve değerlerine saygı gösteren ve etkin bir şekilde yönetilen bir organizasyonda çalışmak isterler.

- Ücret, bir işçinin iş tatmini veya memnuniyetsizliğinin genel düzeyini etkiler (Oshagbemi ve Hickson, 2003, s. 357-367). Çalışanlar ihtiyaçlarını karşılamak için adil ve yeterli ödeme isterler (Henne ve Locke, 1985, s. 221-240).

- Terfi, daha yüksek statü, artan sorumluluk ve/veya daha yüksek maaşla bir pozisyona ilerlemeyi ifade eder (Jackson ve Schuler, 2000, s. 265).

Çalışma ortamı çalışanların ihtiyaçlarını ve değerlerini ne kadar önemsiyorsa, çalışanların işlerinden o kadar memnun kaldıkları ortaya çıkar (Papoutsis vd., 2014).

İş tatminini etkileyen faktörler 4 kategoriye ayrılmaktadır: çevresel faktörler, stratejik çalışan tanınma faktörleri, bireysel faktörler ve psikolojik refah faktörleridir.

a) Çevresel faktörler arasında iletişim türü ve ast-üst ilişkisi yer almaktadır.

b) Stratejik çalışan tanıma faktörleri arasında finansal yönler ve işyeri kültürü ve sosyalizasyonu, ve bu faktörlerin memnuniyeti nasıl etkilediği bulunmaktadır.

c) Bireysel faktörler, çalışanların duygularını ve ruh hallerini, genetiğini ve ekiplerle veya bireylerle çalışma şeklini, problem çözme kabiliyetini, yabancılaşma ve kontrol odağı gibi kişilik özelliklerini içerir.

d) Psikolojik refah faktörleri, çalışanın yaşamının birincil yönleriyle ilgilidir: iş, aile, topluluk vb. (Rothbard, 2001).

\section{İ̧̧e Adanmışlık}

Adanmışlık, organizasyonel hedeflere yönelik odaklanmış enerjiyi ifade eder (Macey vd. 2009, s. 5). İşe adanmışlık, bireyin işini gerçekleştirirken istikrarlı, olumlu, duygusal-motivasyona sahip olma durumu olarak tanımlanır (Maslach vd., 2001, s. 417) ve basit bir deyişle enerji ile yüklü olmak ve tamamen işine adanmış olmaktır. İşe adanmışlık konusunda ilk teori ortaya koyanlardan birisi olan Kahn (1990), adanmış çalışanları fiziksel (physical), bilişsel (cognitive) ve duygusal (emotional) olarak tamamen çalışma rolleriyle bağlantılı olduklarını nitelendirmektedir.

a) Physical (fiziksel) adanmışlık, iş görenin yüksek tempolu bir şekilde işini gerçekleştirmesi, tüm gücünü kullanması, işinde yüksek performans elde etmek için tüm enerjisini işi için tüketmesi, anlamına gelmektedir (Rich vd., 2010). Kahn (1990), çalışmalarına fiziksel olarak adanmış olan kişilerin üretkenliklerinin artacağ ifadelerde bulunmaktadır. Buna paralel olarak fiziksel adanmışlık gösteren çalışanların örgütteki performanslarında meydana gelen artışların, örgütün diğer çalışanları için de 
pozitif bir dürtü oluşturacağından diğer çalışanları da harekete geçirerek yüksek verimlilik meydana geleceğini belirtmektedir (Kahn 1990).

b) Cognitive (Bilişsel) adanmışlık, kişinin sadece bedenen değil, akıl olarakda kendini işine vermesi, işinde dikkatli davranması ve basit hatalar yapmaması, işin onu cezbetmesi, işine özen göstermesi şeklinde açıklanmaktadır (Rich vd., 2010). Bilişsel/cognitive adanmışlık, çalışanların, kurumlarının onlardan neler istediğinin bilincinde olmaları halidir. Bilişsel adanmışlık ile çalışanlar yükümlülüklerinin daha çok bilincinde olduklarından dolayı, iş performanslarında artışlar olacağı gibi, çalışanlarının yükümlülüklerini yerine getirmesi daha basit olacaktır (Kahn, 1990). İşe adanmışlık en çok "enerji, bağllık ve kendini verme ile şekillenmiş pozitif, tatmin edici ve çalışmalar ile alakalı bilinçli olma durumu” olarak tanımlanmaktadır (Schaufeli vd., 2002).

c) Emotional (Duygusal) adanmışlık ise, çalışanın iş yerinde arzulu olması, enerjili hissetmesi, işine alaka göstermesi, işiyle gururlanması, işiyle ilgili pozitif duygulara beslemesi ve işini severekten ifa etmesi anlamına gelmektedir (Rich vd., 2010).

d) Son yirmi yılda, işe adanmışlık konusundaki çalışmaların sayısı hızla artmaktadır. İşe adanmışlık, yüksek adanmışlık düzeyi ve işe güçlü bir şekilde odaklanmanın sonucunda ortaya çıkan enerjili ve heyecanlı bir durumu ifade etmektedir (Schaufeli ve Bakker, 2010). Günümüzdeki kamu ve özel kuruluşların çalışanların ilgisini çekmesi son derece arzu edilen bir durumdur çünkü adanmışlı̆̆ın, yüksek düzeyde yaratıclık, görev performansı, örgütsel bağlllık ve müşteri memnuniyeti ile sonuçlandığı görülmektedir (Bakker vd., 2014).

İşe adanmışlı̆̆ın iş tatmininden farklı olan tarafı, işe adanmışlık, yüksek aktivasyon gösterme, yüksek enerji (vigor) ve kendini verme (absorption); iş tatmini ise genellikle mutluluğunun daha pasif bir şekli olmasıdır. Bu alt faktörler, birinin belirli hedeflere ulaşma konusundaki dürtüsünü temsil eder.Vigor, "çalışırken kişinin işine çaba harcamak isteği ve kabiliyetiyle yüksek düzeyde enerji ve zihinsel esneklik" anlamına gelir (Schaufeli vd., 2002).

Absorption, çıkar ilişkilerini göz önünde bulundurmadan, büyük zevk ve dürtüyle faaliyet gösteren, tamamen iç içe geçmiş bir zihin durumu olarak tanımlanan "akışa" benzer olarak kabul edilir (Csikszentmihalyi, 1990).

İşe adanmışlık, iş gören performansını, iş tatminini, işten ayrılma niyetini, müşteri memnuniyetini, kurumsal başarıyı ve firma karlılığını önemli ölçüde etkilediği için örgütsel sağlığın kilit bir göstergesi olarak kabul edilir (Harter vd., 2002).

\section{Literatür Taraması}

Yapılan literatür taraması sonucunda işe adanmışlı konusunun son yıllarda araştırmacılar tarafından üzerinde sıklıkla durulmaya başlanılan konulardan birisi haline geldiği görülmektedir. Özkalp ve Meydan (2015) "Schaufeli ve Bakker Tarafindan Geliştirilmiş Olan İşe Angaje Olma Ölçeğinin Türkçe 'de Güvenilirlik ve Geçerliliğinin Analizi” başlıklı çalışmalarında bir süper market zincirinde çalışan 146 çalışan ile gerçekleştirdikleri araştırma sonucunda işe adanmışlık ile iş tatmini arasında ,48, duygusal bağlllık ile ,49 ve örgütsel özdeşleşme ile ,50 düzeyinde pozitif anlamlı ilişkiler tespit etmişlerdir. Murray ve arkadaşları (2015), 'Organizational identification, work engagement, and job satisfaction' adlı çalışmalarını 
İngiltere'deki 3 farklı kuruluşta toplam 177 çalışan üzerinde gerçekleştirmiştir. Araştırma sonucuna göre örgütsel özdeşleşme ile iş tatmini arasında pozitif ilişki $(r=0.39, p<0.01)$; Örgütsel özdeşleşme ile işe adanmışlık arasında pozitif ilişki $(r=0.50, p<0.01)$; İşe adanmışlık ile iş tatmini arasında $(r=0.63, \mathrm{p}<0.01)$ pozitif ilişki tespit etmiştir.

Feather ve Rauter (2004) gerçekleştirdikleri araştırmada örgütsel özdeşleşme ile iş tatmini arasında pozitif ,31 düzeyinde anlamlı ilişkiler tespit etmişlerdir. Van Dick ve arkadaşları (2004) dört farklı örneklem üzerinde gerçekleştirdikleri araştırmalarında örgütsel özdeşleşme ile iş tatmini arasında ,21 ile ,52 arasında değişen düzeylerde pozitif ve anlamlı ilişkiler ortaya koymuştur. Amiot ve arkadaşları ise 662 eski havayolu çalışanı ile gerçekleştirdikleri araştırma sonucunda örgütsel özdeşleşme ile iş tatmini arasında ,43 düzeyinde anlamlı ilişkiler ortaya koymuşlardır.

Anaza ve Rutherford (2012) çalışmaları sonucunda örgütsel özdeşleşme ile işe adanmışlık arasında ,38 düzeyinde anlamlı ilişkiler tespit etmişlerdir. Chughtai ve Buckley (2009) ise Pakistan'da öğretmenler üzerine gerçekleştirdikleri çalışma sonucunda örgütsel özdeşleşme ile işe adanmışlık arasında ,35 düzeyinde ilişki tespit etmişlerdir. Ötken ve Erben (2010) İstanbul'da bankacılık, sigortacılık, telekomünikasyon, ilaç ve kimya sektöründe çalışmakta olan 100 beyaz yakalı çalışan ile gerçekleştirdikleri çalışmalarında örgütsel özdeşleşme ile işe adanmışlık alt boyutları arasında anlamlı ilişkiler ortaya koymuşlardır. Gözükara ve Şimsek (2016) özel bir üniversitede çalışmakta olan 252 katılımcıdan elde edilen verilerle yaptıkları analizler sonucunda örgütsel özdeşleşme ile işe adanmışlık arasında pozitif anlamlı ilişkiler tespit etmişlerdir.

Arslan ve Demir (2017) 60 sağlık çalışanı ile gerçekleştirdikleri araştırma sonucunda işe adanmışlık ile iş tatmini arasında ,634 düzeyinde pozitif ilişki tespit etmişlerdir. Giallonardo ve arkadaşları (2010) ise hemşireler üzerinde gerçekleştirdikleri çalışmada işe adanmışlık ile ,39 düzeyinde ilişki tespit etmişlerdir. Shamaa ve arkadaşları (2015) işe adanmışlık ile iş tatmini arasında ,692 ve işe adanmışlık ile örgütsel bağlılık arasında ,795 düzeyinde ilişkiler ortaya koymuşlardır.

\section{Araştırmanın Yöntemi}

\section{Araştırmanın Amacı, Hipotezleri ve Modeli}

Araştırmanın amacı örgütsel özdeşleşmenin iş tatmini üzerine etkisinde işe adanmışlığın aracılık rolünün tespit edilmesidir. Bu doğrultuda araştırmanın hipotezi aşağıdaki şekilde belirlenmiştir.

$\mathrm{H}_{1}$ : Örgütsel özdeşleşmenin iş tatmini üzerine etkisinde işe adanmışlığın aracı rolü vardır.

Araştırmanın modeli Şekil 1'de görüldüğü gibidir. 


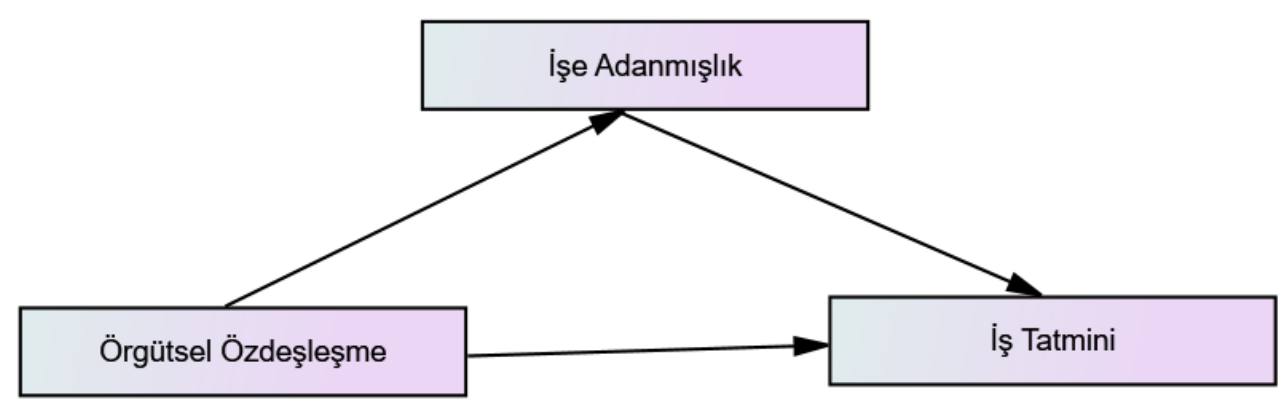

Şekil 1. Araştırma Modeli

\section{Evren ve Örneklem}

Hazırlanan anket formu, Kayseri'de faaliyet göstermekte olan kamu hastanelerinde çalışmakta olan sağlık personeline uygulanmıştır. Kolayda örneklem yöntemi ile 500 anket formu dağıtılmış, toplamda geri dönen anket formları içerisinden eksik cevaplananlar çıkarıldıktan sonra 427 anket çalışmaya dahil edilmiştir.

\section{Ölçüm Araçları}

Araştırma, katılımcıların araştırma değişkenlerine ilişkin görüşlerini tespit etmek için geliştirilmiş olan anket formu aracılığıyla gerçekleştirilmiştir. Anket formunu hazırlanmasında Schaufeli ve Bakker (2003) tarafından geliştirilen 9 ifade ve 3 boyuttan oluşan işe adanmışlık ölçeği, Judge ve arkadaşları (1998) tarafından geliştirilmiş 5 ifade ve tek boyuttan oluşan iş tatmini ölçeği ve Van Dick, Wagner ve Oliver (2004) tarafından geliştirilen 7 ifade ve tek boyuttan oluşan örgütsel özdeşleşme ölçeği kullanılmıştır. Anket çalışması için beşli Likert ölçeği esas alınmıştır.

Yapılan güvenilirlik analizi sonucunda Cronbach's Alpha katsayıları sırası ile işe adanmışlık ölçeği için ,811, iş tatmini ölçeği için ,759 ve örgütsel özdeşleşme ölçeği için ,763 olarak hesaplanmıştır. Bu sonuçlar elde edilen verilerin güvenilir olduğunu göstermektedir.

\section{Bulgular}

\section{Demografik Bulgular}

427 katılımcının demografik özellikleri incelendiğinde katılımcıların büyük bir çoğunluğunun kadın olduğu (326 kadın, 101 erkek), evli olanların sayılarının bekar olanlardan fazla olduğu (302 evli, 125 bekar) olduğu tespit edilmiştir. Eğitim düzeyi itibariyle çalışanların 71,6'sının lisans mezunu olduğu ve örneklemin yaş ortalamasının 33,44 olduğu hesaplanmıştır. Örneklemden elde edilen demografik bulguların sağlık sektöründe çalışan işgörenlerin genel karakteristiğini sergilediği söylenebilir.

\section{Araştırma Değişkenleri île ilgili Bulgular}

\section{Araştırma Değişkenlerine ilişkin Tanımlayıcı İstatistikleri}

Ölçeklerde yer alan ifadelerine verilen cevapların ortalama, standart sapma ve varyans değerleri Tablo 1'de verilmiştir. 
Tablo 1. Araştırma Değişkenlerine İlişkin Ortalama, Standart Sapma ve Varyans Değerleri

\begin{tabular}{|l|r|r|r|}
\hline & Ortalama & Standart Sapma & Varyans \\
\hline $\begin{array}{l}\text { Örgütsel } \\
\text { Özdeşleşme }\end{array}$ & 3,4333 &, 29714 &, 088 \\
\hline İşe Adanmışlık & 3,7431 &, 47465 &, 225 \\
\hline İş Tatmini & 3,9833 &, 70775 &, 501 \\
\hline
\end{tabular}

Katılımcıların verdiği cevaplardan hareketle hesaplanan ortalama değerlerinin 3,43 ile 3,98 arasında değiştiği ve standart sapma değerlerinden hareketle katılımcıların birbirine yakın cevaplar verdiği görülmektedir. Ayrıca her bir ifadeye ilişkin çarpıklık ve basıklık değerlerinden hareketle elde edilen verilerin normal dağılım varsayımını karşıladığı tespit edilmiştir.

\section{Doğrulayıcı Faktör Analizi Sonuçları}

Tablo 2'de araştırma modelinde yer alan değişkenlerin doğrulayıcı faktör analizi sonuçları görülmektedir. DFA verilerinden elde edilen bir modeli doğru bir şekilde tanımlamak için tek bir istatistiksel anlamlılık testi yeterli değildir ve çeşitli kriterlere göre değerlendirilmelidir. Uyum iyiliği indekslerinden elde edilen sonuçlardan hareketle değişkenlere ilişkin yapıların doğrulandığını göstermektedir. Böylece değişkenlerle ilgili yapıların analizde kullanılan ampirik verilerle tutarlı ve uygun olduğu anlaşılmaktadır.

Tablo 2. Doğrulayıcı Faktör Analizi Sonuçları

\begin{tabular}{|c|c|c|c|c|c|c|}
\hline Endeksler & İyi Uyum & $\begin{array}{l}\text { Kabul Edilebilir } \\
\text { Uyum }\end{array}$ & 离 & 豝 & 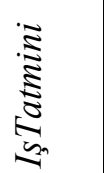 & 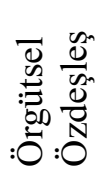 \\
\hline CFI & $, 970 \leq \mathrm{CFI} \leq 1,000$ &, $950 \leq \mathrm{CFI} \leq, 970$ & ,973 & ,997 & ,994 & 966 \\
\hline HOELTER & $\geq 200$ & $75 \leq$ HOELTER $\leq 200$ & 210 & 250 & 464 & 224 \\
\hline IFI & $950 \leq \mathrm{IFI} \leq 1,000$ & $900 \leq \mathrm{IFI} \leq 950$ & 973 & 997 & 999 & 966 \\
\hline NFI & $, 950 \leq \mathrm{NFI} \leq 1,000$ &, $900 \leq \mathrm{NFI} \leq, 950$ & ,963 & 989 & ,975 & ,953 \\
\hline PCLOSE & $\geq 0,05$ & & ,912 & ,925 & ,393 &, 153 \\
\hline RFI & $, 900<\mathrm{RFI} \leq 1,000$ &, $850<\mathrm{RFI} \leq, 900$ & 940 & ,985 & ,991 & ,910 \\
\hline RMSEA &, $000 \leq \mathrm{RMSEA} \leq, 050$ &, $050 \leq \mathrm{RMSEA} \leq, 080$ & 050 & 027 & 043 &, 065 \\
\hline TLI & $, 95 \leq \mathrm{TLI} \leq 1,000$ &, $900 \leq \mathrm{TLI} \leq, 950$ & ,956 & ,983 & ,984 & ,934 \\
\hline$\chi^{2 / \mathrm{df}}$ & $, 000 \leq \chi 2 / \mathrm{df} \leq 2,000$ & $2 \leq \chi 2 / \mathrm{df} \leq 3$ & 3,730 & 1,198 & 2,179 & 3,404 \\
\hline
\end{tabular}

Kaynak: (Hooper and Mullen 2008; Wang and Wang, 2012)

\section{Korelasyon Analizi Sonuçları}

Araştırmanın bu aşamasında araștırma modelinin test edilebilmesi için korelasyon analizinden faydalanılmıştır. Korelasyon analizi, ilgili analizlerin pazarlama araştırmalarında yaygın olarak kullanılmaktadır. Doğrusal ilişkileri ortaya çıkarmaya yarayan korelasyon katsayısı -1 ile +1 arasında bir değerdir. Katsayı pozitif ise, değişkenlerden biri artarken diğeri de artıyor; negatif ise, değişkenlerden biri artarken diğeri azalıyor demektir. Değişkenler arasındaki ilişki düzeyleri tabloda görüldüğü gibidir. 
Tablo 3. Korelasyon Analizi Sonuçları

\begin{tabular}{|l|r|r|r|r|}
\hline Değişkenler & \multicolumn{1}{|c|}{$\mathbf{1}$} & \multicolumn{1}{|c|}{$\mathbf{2}$} & \multicolumn{1}{|c|}{$\mathbf{3}$} & $\mathbf{4}$ \\
\hline Örgütsel Özdeşleşme & 1 & & & \\
\hline İşe Adanmışlık &, $416^{* *}$ & 1 & & \\
\hline İş Tatmini &, $436^{* *}$ &, $605^{* *}$ & 1 & \\
\hline
\end{tabular}

Korelasyon analizi sonucunda örgütsel özdeşleşme ile işe adanmışlık arasında pozitif \%41,6 düzeyinde, örgütsel özdeşleşme ile iş tatmini arasında pozitif \%43,6 düzeyinde ve işe adanmışlık ile iş tatmini arasında pozitif \%60,5 düzeyinde ilişki olduğu görülmektedir.

\section{Araştırma Hipotezinin Test Edilmesi}

Aracılık hipotezlerini incelemek için Preacher ve Hayes'in (2004) ortaya koyduğu bootstrap yöntemi kullanılmıştır. Bu yaklaşım, aracılı̆̆ın dolaylı etkilerini test etmek için büyük veri setleri oluşturması, yanlılığı azalması ve hızlandırılmış güven aralıklarının hesaplanmasına izin vermektedir. Preacher ve Hayes'in (2004) yaklaşımı, Baron'un ve Kenny'nin (1986) yaklaşımı yerine, daha büyük örneklem büyüklükleri gerektiren normallik sapmalarına duyarlılığ konusundaki sınırlamaları nedeniyle tercih edilmektedir. Ayrıca eski yöntemlere kıyasla örneklemi artırdığından dolayı aracılık analizlerinde yapısal eşitlik modelinin kullanılması tercih edilmektedir. Analizlerin yapılmasında IBM SPSS ve PROCESS 3.2. programlarından faydalanılmıştır.

Araştırma hipotezini test etmek için yapılan regresyon analizi sonuçları Şekil 2'de görüldüğü gibidir. Şekilden hareketle örgütsel özdeşleşmenin iş tatminini anlamlı olarak etkilediği (b = $1,0396, \mathrm{SE}=0,1040, \mathrm{t}=10,0011, \mathrm{p}=, 000)$ ve iş tatmininde meydana gelen değişimin $\left(\mathrm{R}^{2}\right)$ \%19,05’inin açıkladığı görülmektedir. Örgütsel özdeşleşmenin işe adanmışlığı anlamlı olarak açıkladığı $(b=0.66, S E=0.0705, t=9,42, p=, 000)$ ve örgütsel özdeşleşmenin işe adanmışlıkta meydana gelen değişimin \%17,3'ünün açıkladığı görülmektedir Ayrıca, örgütsel özdeşleşme $(b=0,5331, \mathrm{SE}=0,0979, \mathrm{t}=5,44, \mathrm{p}=, 000)$ ve işe adanmışlığın $(\mathrm{b}=0.7627, \mathrm{SE}=$ $0,0613, \mathrm{t}=12,44, \mathrm{p}=, 000)$ iş tatminini anlamlı olarak açıkladı $\breve{g}_{1}$ ve iki değişkenin birlikte iş tatminindeki varyansın \%40,7’sinin açıkladığı tespit edilmiştir. 


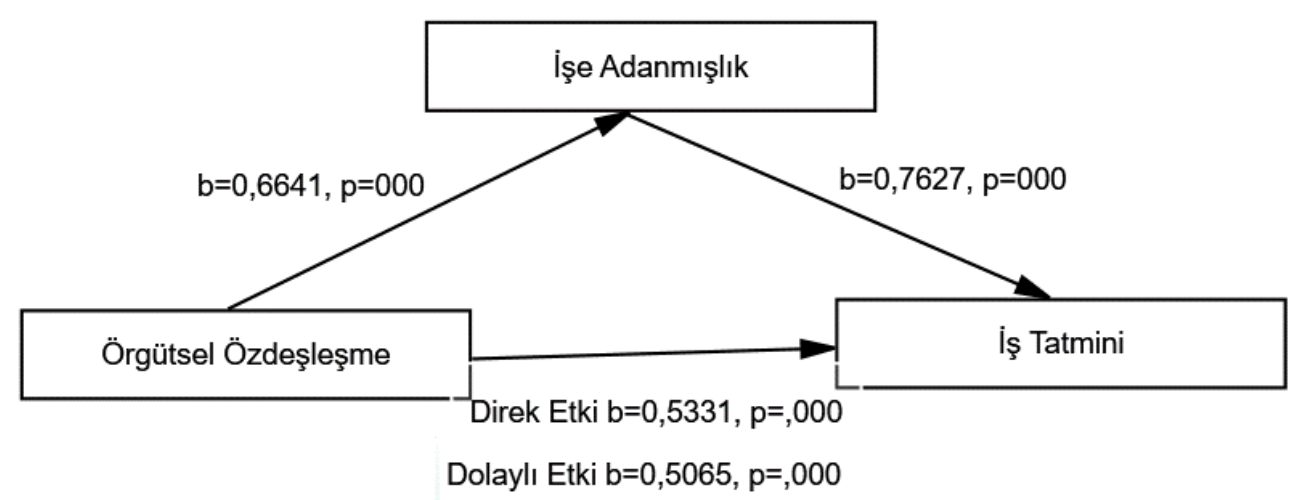

Not: Aracılık analizi BCa bootstrapped yöntemiyle örneklemin 10.000’e çıarılmasıyla \%95 güven aralığında gerçekleştirilmiştir.

\section{Şekil 2. Regresyon Analizi Sonuçları}

Regresyon analizleri sonucunda örgütsel özdeşleşmenin iş tatmini üzerindeki etkisinde b = 1,0396 iken analize çalışmanın aracı değişkenin olan işe adanmışlığın eklenmesi ile birlikte b = 0,5331 şeklinde azaldığ görülmektedir. Bu bulgulardan hareketle örgütsel özdeşleşmenin iş tatmini üzerine etkisinde işe adanmışlığın aracı rol oynadığı sonucu ortaya konulmuştur.

\section{Sonuç ve Tartışma}

Sosyal Kimlik Teorisi ve örgütsel kimlik kavramına dayanarak, çalıștıkları örgütü kişisel değerleriyle tutarlı ve öz tanımlarının bir parçası olarak gören işgörenler yaptıkları işi daha fazla severek çalıştıkları örgütten daha memnun olurlar. Yapılan analizler kurulan araştırma modelini doğrulamaktadır. Araştırma bulguları örgütsel özdeşleşmenin iş tatmini üzerinde pozitif yönlü güçlü bir etkiye sahip olduğunu göstermektedir. Bunun yanında örgütsel özdeşleşme iş tatmini üzerideki etkisini bir kısmını işe adanmışlık yoluyla aktarmaktadır. Çalıştıkları örgüt ile arasında güçlü bir bağa sahip olan işgörenler yaptıkları işe önem verir, yaptıkları işe kendilerini adarlar ve bunların sonucunda iş tatmini duyguları artar.

Yüksek derece örgütleriyle özdeşleşen ve yüksek işe adanan işgörenler, yaptıkları işin olumsuz yönlerine daha kuvvetli bir şekilde tepki vererek iş tatminleri aniden düşebilir. Gerçekten de işyerinde son derece meşgul olan bireylerin işyerinde karşılaşılan olumsuz olaylardan daha olumsuz etkilenerek bunun sonucunda işle ilgili stres faktörlerinden daha fazla etkilenirler. İşleriyle yüksek derece adanmışlık yaşayan bireyler mesaiden sonra psikolojik olarak ayrılamayabilirler. Bu durum da işgörenlerin kişisel aktivitelerine müdahale ederek bireyin genel iş değerlendirmesinin olumsuza dönmesine neden olabilir. Yüksek derecede örgütsel özdeşleşme ve işe adanmışlık sonucunda bireyde aşırı çalışma hissine bağlı olarak işkoliklik ortaya çıkabilir. Tüm bu olumsuz beklentiler konu ile ilgili araştırma sayısının artırılarak karşılaştırma yapılmasını gerekli kılabilir.

$\mathrm{Bu}$ çalışmada örgütsel özdeşleşme ile iş tatmini arasındaki ilişkide işe adanmışlık bağlantı noktası olduğu belirlenmiştir. Kimlik bireylerin tutumlarının oluşmasında etkili olan bir unsurdur. Örgüt kimlik de örgüt içerisindeki tüm işgörenlerin davranışlarının açıklanması 
noktasında önemli bir değişkendir. Örgüt içerisinde çalışanların örgüt ile özdeşleşme düzeylerini artırabilmek için aşağıdaki önerilerde bulunulabilir:

- İş yerinin çalışanların temel psikolojik ihtiyaçlarını karşılayacak şekilde tasarlanması,

- Günlük çalışmaya katılımı destekleyen bir örgüt kültürü oluşturulması,

- Geri bildirim yoluyla işgörenlerin örgütün hedeflerine ulaşma noktasında sağladığı katkıların iletilmesi,

- Alınacak kararlar noktasında işgörenlerin fikirlerine başvurulması,

- Destekleyici bir çalışma ikliminin oluşturularak çalışanların güçlendirilmesi.

Belirli bir örgütün üyesi olma, örgütün değerlerine ve hedeflerine uyum gösterme, çalışanların işle ilgili biliş, tutum ve davranışlarıyla bağlantılıdır. Sosyal Kimlik Teorisine dayandırılan bu çalışma, çalışanların işe adanmışlık düzeylerinin örgütsel özdeşleşme ile iş tatmini arasındaki ilişkide nasıl bir rol oynadığını tespit etmeye çalışmıştır. Bu bulgular ulusal literatüre yeni bilgilerle katkıda bulunurken, bu alanda gelecekteki araştırmalar için de yeni zorluklar getirmektedir

Çalışma kapsamında dikkat edilmesi gereken bazı kısıtlar söz konsuudur. Hazırlanan anket formu aracılığı ile katılımcılardan kesitsel veri toplanması yoluna gidilmiştir. Bu durum bazı kısıtlamaları beraberinde getirmektedir. Ayrıca katılımcıların kendilerine yönetilen ifadelere tarafsız ve gerçek bir şekilde cevap verdikleri varsayılmaktadır. Araştırma örneklemi zaman ve maliyet kısıtları nedeniyle sadece Kayseri'deki faaliyet göstermekte olan hastanelerde çalışmakta olan katılımcılar ile sınırlı tutulmuştur. Bu durum ise elde edilen sonuçların diğer sektörlere veya sağlık sektörünün tamamına genellenmesi noktasında engel teşkil etmektedir.

\section{Kaynakça}

Abraham, S. (2012). Development of employee engagement programme on the basis of employee satisfaction survey. Journal of Economic Development, Management, IT, Finance, and Marketing, 4(1), 27-37.

Abu-Shamaa, R., Al-Rabayah, W. A., \& Khasawneh, R. T. (2015). The Effect of Job Satisfaction and Work Engagement on Organizational Commitment. IUP Journal of Organizational Behavior, 14(4).

Albdour, A. A., \& Altarawneh, I. I. (2014). Employee engagement and organizational commitment: Evidence from Jordan. International Journal of Business, 19(2), 192-212.

Amiot, C. E., Terry, D. J., Jimmieson, N. L., \& Callan, V. J. (2006). A longitudinal investigation of coping processes during a merger: Implications for job satisfaction and organizational identification. Journal of Management, 32(4), 552-574.

Anaza, N. A., \& Rutherford, B. (2012). How organizational and employee-customer identification, and customer orientation affect job engagement. Journal of Service Management, 23(5), 616-639. 
Arslan, E. T. \& Demir, H. (2017). İşe angaje olma ve iş tatmini arasındaki ilişki : hekim ve hemşireler üzerine nicel bir araştırma. Yönetim ve Ekonomi Manisa Celal Bayar Üniversitesi İ.İ.B.F., 24(2), 371-389.

Ashforth B.E. \& Mael F. (1989) Social identity theory and the organization. Academy of Management Review, 14, 20-39.

Bakker, A. B., Demerouti, E., \& Sanz-Vergel, A. I. (2014). Burnout and work engagement: The JD-R approach. Annual Review of Organizational Psychology and Organizational Behavior, 1(1), 389-411.

Baron, R. M., \& Kenny, D. A. (1986). The moderator-mediator variable distinction in social psychological research: Conceptual, strategic, and statistical considerations. Journal of Personality and Social Psychology, 51(6), 1173.

Chughtai, A. A., \& Buckley, F. (2009). Linking trust in the principal to school outcomes: The mediating role of organizational identification and work engagement. International Journal of Educational Management, 23(7), 574-589.

Churchill Jr, G. A., Ford, N. M., \& Walker Jr, O. C. (1976). Organizational climate and job satisfaction in the salesforce. Journal of Marketing Research, 13(4), 323-332.

Czikszentmihalyi, M. (1990). Flow: The psychology of optimal experience. New York: Harper \& Row.

Dutton, J.E., Dukerich, J.M. \& Harquail, C.V. (1994). Organisational images and member identification. Administration Science Quarterly, 39, 239- 263.

Edwards, M. R. (2005), Organizational identification: A conceptual and operational review. International Journal of Management Reviews, 7, 207-230.

Edwards, M. R., \& Peccei, R. (2007). Organizational identification: Development and testing of a conceptually grounded measure. European Journal of Work and Organizational Psychology, 16(1), 25-57.

Feather, N. T., \& Rauter, K. A. (2004). Organizational citizenship behaviours in relation to job status, job insecurity, organizational commitment and identification, job satisfaction and work values. Journal of Occupational and Organizational Psychology, 77(1), 81-94.

Giallonardo, L. M., Wong, C. A., \& Iwasiw, C. L. (2010). Authentic leadership of preceptors: predictor of new graduate nurses' work engagement and job satisfaction. Journal of Nursing Management, 18(8), 993-1003.

Gözükara, İ., \& Simsek, Ö. F. (2016). Role of leadership in employees' work engagement: Organizational identification and job autonomy. International Journal of Business and Management, 11(1), 72-84.

Harter, J. K., Schmidt, F. L., \& Keyes, C. L. (2003). Well-being in the workplace and its relationship to business outcomes: A review of the Gallup studies. Flourishing: Positive Psychology and the Life Well-lived, 2, 205-224. 
Henne, D., \& Locke, E. A. (1985). Job dissatisfaction: what are the consequences?. International Journal of Psychology, 20(2), 221-240.

Jackson, S. E. and Schuler, R. S. (2000). Managing Human Resources, 7th Edition, New York: Sauth-Western Collage.

Judge, T. A., Locke, E. A., Durham, C. C., \& Kluger, A. N. (1998). Dispositional effects on job and life satisfaction: The role of core evaluations. Journal of Applied Psychology, 83(1), 1734.

Kahn, W.A. (1990). Psychological Conditions of Personal Engagement and Disengagement at work. Academy of Management Journal, 33, 692-724.

Karanika-Murray, M., Duncan, N., Pontes, H. M., \& Griffiths, M. D. (2015). Organizational identification, work engagement, and job satisfaction. Journal of Managerial Psychology, 30(8), 1019-1033.

Kelman, H.C. (1958). Compliance, identification, and internalization: three processes of attitude change. Journal of Conflict Resolution, 2, 51-60.

Kreitner, R. \& Kinicki, A. (2004). Organizational Behavior, 6th Edition, New York: McGrawHill.

Larson, G. S., \& Pepper, G. L. (2003). Strategies for managing multiple organizational identifications: A case of competing identities. Management Communication Quarterly, 16, 528-557.

Lee S.M. (1971) An empirical analysis of organizational identification. Academy of Management Journal, 14(2), 213-226.

Macey W.H., Schneider B., Barbera K.M. \& Young S.A. (2009). Employee engagement: Tools for analysis, practice and competitive advantage. Oxford, UK: Wiley-Blackwell.

Mael, F.A. \& Ashforth, B.E. (1992). Alumni and their alma mater; a partial test of a reformulated model of organisational identification. Journal of Organisational Behaviour, 13(2), 103123.

Maslach, C., Schaufeli, W. B., \& Leiter, M. P. (2001). Job burnout. Annual Review of Psychology, 52(1), 397-422.

Mowday, R. T., Porter, L. M. \& Steers, R. M., (1982). Employee-Organizational Linkage, New York Academic.

Oshagbemi, T. (2003). Personal Correlates of Job Satisfaction: Empirical Evidence from UK Universities, International Journal of Social Economics, 30(12), 1210-1232.

Oshagbemi, T. (2003). Personal correlates of job satisfaction: empirical evidence from UK universities. International Journal of Social Economics, 30(12), 1210-1232.

Ötken, A. B., \& Erben, G. S. (2010). Investigating the relationship between organizational identification and work engagement and the role of supervisor support. Gazi Universitesi Iktisadi ve Idari Bilimler Fakultesi Dergisi, 12(2), 93-118. 
Özkalp, E., \& Meydan, B. (2015). Schaufeli ve Bakker tarafindan geliştirilmiş olan İşe Angaje Olma ölçeğinin Türkçe'de güvenilirlik ve geçerliliğinin analizi. ISGUC The Journal of Industrial Relations and Human Resources, 17(3), 1-19.

Papoutsis, D., Labiris, G., \& Niakas, D. (2014). Midwives' job satisfaction and its main determinants: A survey of midwifery practice in Greece. British Journal of Midwifery, 22(7), 480-486.

Patchen, M. (1970). Participation, Achievement and Involvement in the Job. Englewood Clifs, NJ: Prentice Hall.

Preacher, K. J., \& Hayes, A. F. (2004). SPSS and SAS procedures for estimating indirect effects in simple mediation models. Behavior Research Methods, Instruments, \& Computers, 36(4), 717-731.

Rich, B. L., Lepine, J. A., \& Crawford, E. R. (2010). Job engagement: Antecedents and effects on job performance. Academy of Management Journal, 53(3), 617-635.

Richman, A. (2006), Everyone wants an engaged workforce how can you create it?, Workspan, 49(1), 36-39.

Robbins, S. P. (2000). Essentials of Organizational Behavior, Sixth Edition, New Jersey: Prentice Hall.

Rothbard. N. P. (2001). Enriching or Depleting? The Dynamics of Engagement in Work and Family Roles, Administrative Science Quarterly, 46, 655-684.

Rousseau, D.M. (1998). Why workers still identify with organisations. Journal of Organisational Behaviour, 19, 217-233.

Schaufeli, W.B. \& Bakker, A.B. (2010), "Defining and measuring work engagement: bringing clarity to the concept", in Bakker, A.B. and Leiter, M.P. (Eds), Work Engagement: A Handbook of Essential Theory and Research, New York, NY: Psychology.

Schaufeli, W.B., \& Bakker, A. B. (2003). UWES-Utrecht work engagement scale: test manual, Department of Psychology, Utrecht University, Utrecht.

Schaufeli, W.B., Salanova, M., González-Romá, V. \& Bakker, A.B. (2002), The measurement of engagement and burnout: a two sample confirmatory factor analytic approach, Journal of Happiness Studies, 3(1).. 71-92.

Tajfel, H. (1978). Social categorization, social identity and social comparison. Differentiation Between Social Group, 61-76.

Van Dick, R., Wagner, U., Stellmacher, J., \& Christ, O. (2004). The utility of a broader conceptualization of organizational identification: which aspects really matter?. Journal of Occupational and Organizational Psychology, 77(2), 171-191. 